\title{
KOMPARASI AKURASI METODE CORRELATED NAIVE BAYES CLASSIFIER DAN NAIVE BAYES CLASSIFIER UNTUK DIAGNOSIS PENYAKIT DIABETES
}

\author{
Hairani, Gibran Satya Nugraha, Mokhammad Nurkholis Abdillah, Muhammad Innuddin \\ STMIK Bumigora Mataram \\ Jl. Ismail Marzuki, Cilinaya, Cakranegara, Kota Mataram, Nusa Tenggara Bar. 83127, Indonesia \\ hairani@stmikbumigora.ac.id, gibransn@stmikbumigora.ac.id,nurkholisabdillah@stmikbumigora.ac.id, \\ inn@stmikbumigora.ac.id
}

\begin{abstract}
Abstrak- Penyakit diabetes merupakan salah satu penyakit paling banyak diderita oleh manusia seluruh dunia. Setiap tahun terjadi peningkatan kematian yang disebabkan oleh penyakit diabetes. Penyakit diabetes terjadi disebabkan oleh tubuh tidak menghasilkan insulin dalam jumlah yang cukup. Salah satu cara yang digunakan untuk mengurangi jumlah kematian yang disebabkan oleh penyakit diabetes adalah melakukan diagnosis secara dini. Salah satu teknik yang bisa digunakan adalah memanfaatkan teknik data mining. Untuk melakukan diagnosis penyakit diabetes dibutuhkan suatu metode yang memiliki akurasi terbaik. Pada penelitian ini melakukan komparasi metode Correlated-Naive Bayes Classifier dan Naive Bayes Classifier untuk mendapatkan akurasi terbaik sehingga dapat digunakan untuk diagnosis penyakit diabetes. Berdasarkan pengujian yang telah dilakukan menunjukkan bahwa metode Correlated Naive Bayes Classifier (CNBC) memperoleh akurasi terbaik dibandingkan dengan metode Naive Bayes Classifier (NBC) untuk Dataset Pima indian Diabetes. Tingkat akurasi metode Correlated Naive Bayes Classifier (CNBC) sebesar $67,15 \%$, sedangkan metode Naive Bayes Classifier (NBC) sebesar $64,33 \%$. Metode Correlated Naive Bayes Classifier (C-NBC) memiliki akurasi lebih tinggi dibandingkan metode Naïve Bayes Classifier (NBC) karena pada metode Correlated Naïve Bayes Classifier memperhitungkan nilai korelasi dari masing-masing atribut dataset terhadap Kelasnya. Dengan demikian penggunaan metode Correlated Naïve Bayes Classifier (C-NBC) dapat digunakan untuk melakukan diagnosis penyakit diabetes karena memiliki tingkat akurasi yang bagus dibandigkan metode Naive Bayes Classifier.
\end{abstract}

Keywords - data mining; correlated naive bayes classifier; naïve bayes classifier; diabetes.

\section{PENDAHULUAN}

Penyakit diabetes merupakan salah satu penyakit paling banyak diderita oleh manusia seluruh dunia. Menurut WHO (Word Health Organization) melaporkan bahwa penderita penyakit diabetes didunia mendekati jumlah 350 juta orang. Pada tahun 2012 dilaporkan sekitar 1,5 juta kematian disebabkan oleh penyakit diabetes, lebih dari $80 \%$ dari jumlah kematian tersebut terjadi di negara-negara berkembang [1]. WHO memprediksikan bahwa tahun 2030 penyakit diabetes menjadi salah satu dari 7 faktor penyebab utama terjadinya kematian didunia.

Selain itu bahaya yang ditimbulkan penyakit diabetes adalah kebutaan, amputasi, dan gagal ginjal diakibatkan kurangnya kesadaran masyarakat dunia tentang bahaya penyakit diabetes [2]. Penyakit diabetes disebabkan oleh pankreas tidak bisa memproduksi insulin yang cukup sehingga menyebabkan peningkatan produksi glukosa dalam darah (hiperglikemia). Insulin merupakan sebuah hormon berfungsi mengatur gula darah dan bertanggung jawan untuk menghasilkan energi yang dibutuhkan oleh manusia. Penyakit diabetes sendiri dibagi menjadi 2 jenis yaitu diabetes tipe 1 dan tipe 2 [3].

Pada penelitian-penelitian terdahulu, sudah dilakukan penelitian klasifikasi di bidang kesehatan dengan menggunakan teknik atau algoritme data mining. Penelitian sebelumnya yang masing-masing dilakukan oleh referensi [4][5] sudah mencoba menggunakan beberapa metode atau algoritme data mining diantaranya adalah Naive Bayes, $K-N N$, NBTree, dan Decision Tree. Salah satu penelitian yang dilakukan oleh referensi [5] menggunakan algoritme Decision Tree, Naive Bayes, dan NBTree untuk klasifikasi penyakit liver. Berdasarkan hasil penelitian yang dilakukan menunjukan bahwa metode NBTree memiliki akurasi yang paling tinggi bila dibandingkan dengan Decision Tree dan Naive Bayes yaitu sebesar $67,01 \%$.

Penelitian yang dilakukan oleh referensi [4] mengembangkan metode Correlated-Naive Bayes Classifier atau C-NBC. C-NBC merupakan sebuah pengembangan dari metode Naive Bayes Classfier (NBC) dengan menambahkan paramater korelasi antar atribut terhadap kelas. Dengan memperhitungkan nilai korelasi dari masing-masing atribut vektor $\mathrm{X}$ terhadap kelas $\mathrm{Y}$ dapat meningkatkan akurasi. 
Berdasarkan hasil pengujian yang dilakukan menggunakan 4 dataset yaitu yaitu Dataset Iris, Dataset Balance-Scale, Dataset Haberman, dan Dataset Servo, menunjukkan bahwa metode C-NBC mengalami kenaikan akurasi rata-rata sebesar $13,3 \%$ dibandingkan metode NBC.

Shah \& Jivani [6] menggunakan algoritme Random Forest, Naive Bayes, dan $K-N N$ untuk klasifikasi penyakit kanker payudara. Berdasarkan hasil penelitian yang dilakukan menunjukan bahwa metode Naive Bayes memiliki akurasi yang paling tinggi bila dibandingkan dengan Random Forest dan $K-N N$ yaitu sebesar $95,99 \%$. Kelemahan penelitian ini adalah tidak menjelaskan tahapan data pre-processing sebelum ketahapan proses klasifikasi dengan teknik data mining.

Berdasarkan uraian masalah diatas untuk mengurangi jumlah kematian yang disebabkan oleh penyakit diabetes adalah melakukan diagnosis secara dini. Salah satu teknik yang bisa digunakan adalah memanfaatkan teknik data mining. Untuk melakukan diagnosis penyakit diabetes dibutuhkan suatu metode yang memiliki akurasi terbaik, sehingga pada penelitian ini melakukan komparasi beberapa metode klasifikasi data mining yaitu metode Correlated-Naive Bayes Classifier dan Naive Bayes Classifier untuk mendapatkan akurasi terbaik sehingga dapat digunakan untuk diagnosis penyakit diabetes secara efektif.

\section{TINJAUAN PUSTAKA}

\section{A. Data Mining}

Data Mining merupakan suatu proses untuk menggali pengetahuan yang dibutuhkan dari sejumlah data besar. Data mining dan Knowledge Discovery in Database (KDD) secara bergantian menjelaskan proses penggalian informasi tersembunyi dalam kumpulan data yang besar. Sebenarnya kedua istilah tersebut memiliki konsep berbeda, tetapi berkaitan satu sama lain dan salah satu tahap dalam proses KDD adalah Data Mining. Knowledge Disccovery in Database (KDD) merupakan proses yang bertujuan untuk menggali, menganalisis, dan mengekstrak sejumlah data yang besar menjadi sebuah informasi atau pengetahuan yang berguna.

Adapun langkah penting dalam proses Knowledge Discovery in Database (KDD) seperti berikut [7] :

\section{Data Cleaning}

Data cleaning merupakan proses untuk membuang duplikasi data, memeriksa data yang tidak konsisten, dan memperbaiki kesalahan pada data, seperti kesalahan penulisan, data yang hilang.

\section{Data Integration}

Pada tahapan ini melakukan proses menambah data yang sudah ada dengan data atau informasi lain yang relevan atau bisa disebut juga merupakan penggabungan data dari berbagai database kedalam satu database baru yang dibutuhkan oleh KDD.

\section{Data Selection}

Pada tahapan ini melakukan pemilihan data yang relevan dan dapat dilakukan analisis dari data operasional. Data hasil pemilihan disimpan dalam database yang terpisah.

\section{Data Transformation}

Pada tahapan ini melakukan proses transformasi data kedalam bentuk format tertentu sehingga data tersebut sesuai untuk proses data mining. Penelitian ini menggunakan tahapan transformasi data untuk mengubah tipe data non-numerik menjadi data numerik. Hal ini dilakukan untuk menghitung nilai korelasi (R-Square) pada algoritme Correlated Naive Bayes Classifier.

\section{Data Mining}

Pada tahapan ini proses untuk mencari pola atau informasi menarik dengan menggunakan teknik, metode atau algoritme tertentu. Penelitian ini menggunakan algoritme klasifikasi Naive Bayes Classifier dan Correlated Naive Bayes Classifier

\section{Pattern Evaluation}

Pada tahapan ini melakukan proses untuk mengidentifikasi pola-pola yang benar-benar menarik dari hasil data mining. Dalam tahap ini hasil dari teknik data mining berupa pola-pola yang khas maupun model prediksi yang dievaluasi untuk menilai apakah hipotesa yang ada memang tercapai atau tidak.

\section{Knowledge Presentation}

Pada tahap ini proses untuk menampilkan pola informasi yang dihasilkan dari proses data mining, visualisasi ini membantu mengkomunikasikan hasil data mining dalam bentuk yang mudah dimengerti.

\section{B. Metode Correlated Naive Bayes Classifier}

Metode Correlated Naive Bayes Classifier merupakan sebuah pengembangan dari metode Naive Bayes. Pada metode Correlated Naive Bayes Classifier memperhitungkan nilai korelasi (R-Square) antara variabel bebas (X) terhadap variabel terikat (Y). Penambahan paramater korelasi digunakan untuk mengukur tinggi rendahnya derajat hubungan antara variabel bebas $(\mathrm{X})$ terhadap variabel terikat (Y).

Formula metode Correlated Naive Bayes Classifier untuk klasifikasi ditunjukkan pada persamaan 1.

$$
\mathrm{P}(Y \mid X)=\frac{P(Y) \prod_{i=1}^{q} P\left(X_{i} \mid Y\right)^{\tau} \cdot R\left(X_{i} \mid Y\right)}{P(X)} \quad 1
$$

Keterangan :

$\mathrm{X}=$ data dengan kelas yang belum diketahui.

$\mathrm{Y}=$ hipotesis data $\mathrm{X}$ merupakan suatu kelas spesifik.

$\mathrm{P}(\mathrm{X} \mid \mathrm{Y})=$ probabilitas hipotesis $\mathrm{Y}$ berdasarkan kondisi $\mathrm{Y}$.

$\mathrm{P}(\mathrm{Y})=$ probabilitas awal hipotesis $\mathrm{Y}$ (prior probability). $\prod_{i=1}^{q} P\left(X_{\mathrm{i}} \mid Y\right)=$ probabilitas setiap atribut dari data $\mathrm{X}$ berdasarkan kondisi hipotesis $\mathrm{Y}$.

$R\left(X_{\mathrm{i}} \mid Y\right)=\mathrm{R}$ Square setiap atribut dari data $\mathrm{X}$ berdasarkan 


\section{kondisi hipotesis Y.}

$\tau=$ bilangan laplacian.

$\mathrm{P}(\mathrm{X}) \quad=$ probabilitas dari $\mathrm{X}$.

Untuk proses klasifikasi metode Correlated Nä̈ve Bayes Classifier ditunjukkan pada Gambar 1.

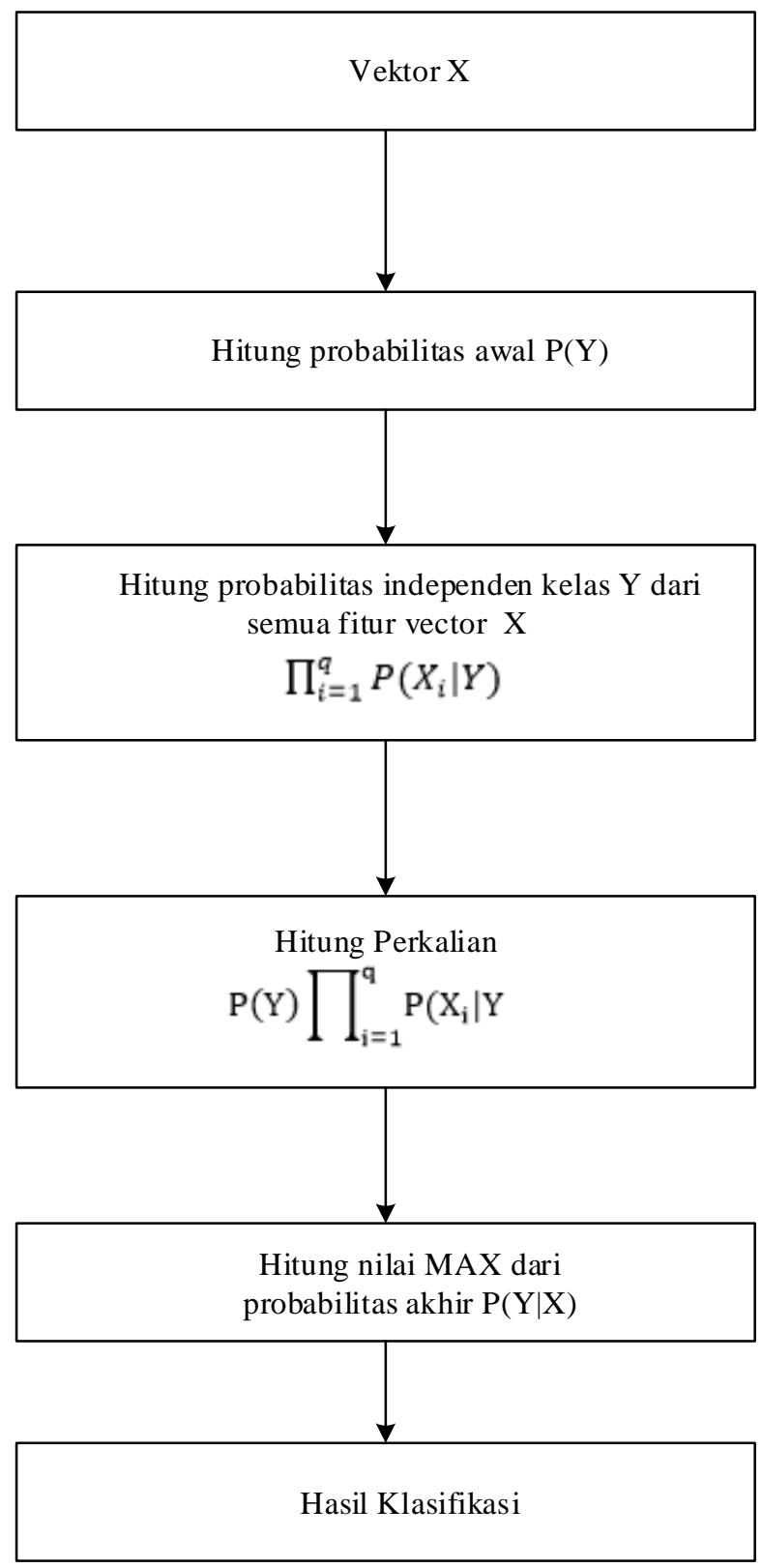

Gbr. 1 Proses Skema Klasifikasi Nä̈ve Bayes Classifier

\section{METODE PENELITIAN}

Penelitian ini dilakukan beberapa tahapan yang ditunjukkan pada Gambar 2 [8].

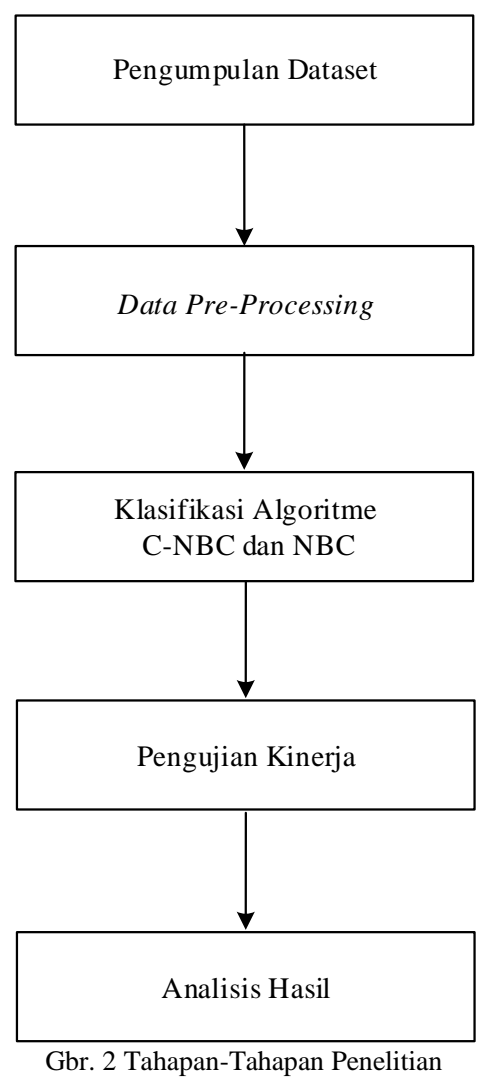

\section{A. Pengumpulan Dataset}

Tahapan pertama yang dilakukan adalah mengumpulkan dataset Pima Indian Diabetes yang diperoleh dari UCI Repository. Dataset Pima Indian Diabetes memiliki jumlah 768 data, 9 atribut, dan 2 kelas. Adapun detail atribut Dataset Pima Indian Diabetes seperti ditunjukkan pada Tabel 1.

TABEL I

ATRIBUT DATASET PIMA INDIAN DIABETES

\begin{tabular}{|l|l|l|}
\hline No. & Atribut & Label \\
\hline 1. & Number of times pregnant & Preg \\
\hline 2. & Plasma glucose concentation & Plas \\
\hline 3. & $\begin{array}{l}\text { Diastoloc blood pressure } \\
(\mathrm{mm} / \mathrm{Hg})\end{array}$ & Pres \\
\hline 4. & $\begin{array}{l}\text { Triceps skin fold thickness } \\
(\mathrm{mm})\end{array}$ & Skin \\
\hline 5. & 2-Hour serum insulin & Insu \\
\hline 6. & Body mass index (kg/m2) & Mass \\
\hline 7. & Diabetes pedigree function & Pedi \\
\hline 8. & Age (years) & Age \\
\hline 9. & $\begin{array}{l}\text { Class (Tested Negative and } \\
\text { Tested Posotive) }\end{array}$ & Class \\
\hline
\end{tabular}

\section{B. Data Pre-Processing}

Tahapan data pre-processing merupakan proses data mining yang pertama kali dilakukan untuk mendapatkan kualitas data sebelum dilakukan proses klasifikasi seperti transformasi data. Tahap transformasi data merupakan salah 
satu bagian terpenting dari proses data pre-processing Transformasi data dilakukan dalam penelitian ini untuk mengubah tipe data atribut dataset pima indian diabetes yang memiliki tipe data non-numerik menjadi tipe data numerik. Hal ini dilakukan untuk memudahkan perhitungan nilai korelasi (R-Square) antar atribut terhadap kelas pada metode Correlated Naive bayes Classifier pada tahap klasifikasi. Hasil dari transformasi tipe data non-numerik menjadi numerik ditunjukkan pada Tabel 2.

TABEL 2

TRANSFORMASI DATA KELAS KE TIPE NUMERIK DATASET PIMA INDIAN DIABETES

\begin{tabular}{|l|l|l|}
\hline No. & Data Non Numerik & Data Numerik \\
\hline 1. & Tested Negative & 1 \\
\hline 2. & Tested Positive & 2 \\
\hline
\end{tabular}

\section{Klasifikasi}

Setelah melalui tahapan pre-processing, dilanjutkan ketahap klasifikasi. Klasifikasi merupakan salah satu tugas dari data mining. Klasifikasi adalah proses untuk menentukan suatu item dari dataset kedalam label kelas. Penelitian ini menggunakan metode klasifikasi Naive Bayes Classifier (NBC) dan Correlated-Naive Bayes Classifier (C-NBC). Proses klasifikasi menggunakan kedua metode tersebut terdiri dari beberapa proses. Alur proses klasifikasi metode Correlated Naive Bayes Classifier ditunjukkan pada Gambar 3 .
Hitung probabilitas awal $\mathrm{P}(\mathrm{Y})$

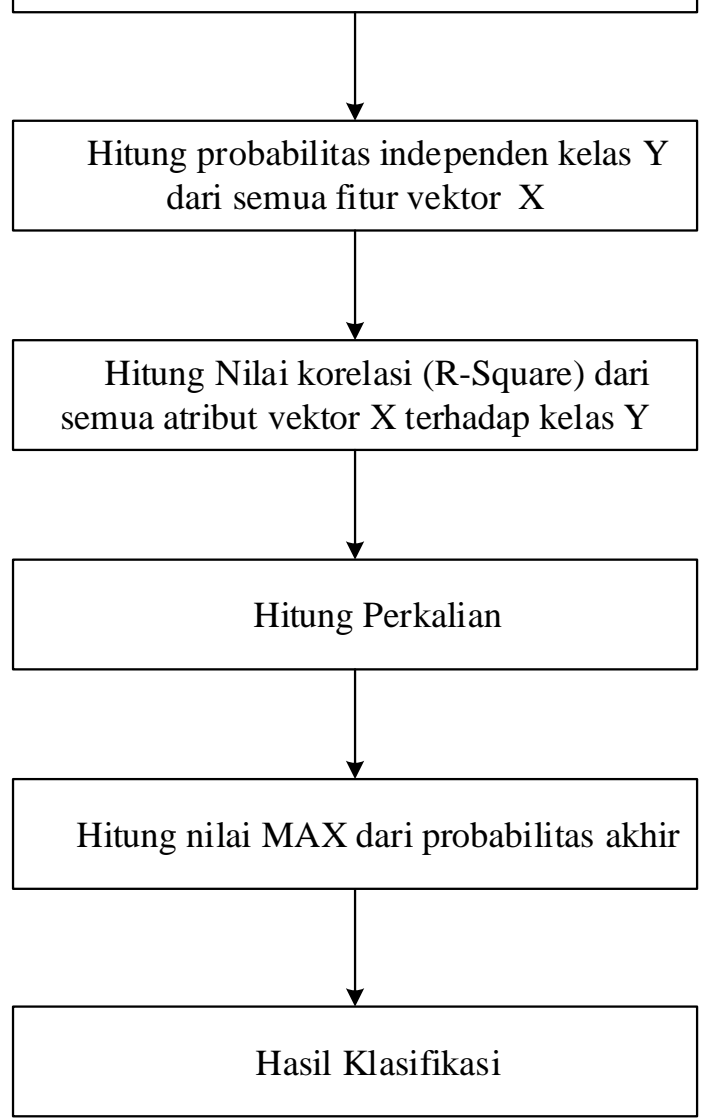

Gbr. 3 Proses Klasifikasi Nä̈ve Bayes Classifier

Pengujian kedua metode tersebut menggunakan $k$-fold cross validation yang bertujuan untuk membagi data kedalam $k$-fold yang diberikan.

\section{IV.HASIL DAN PEMBAHASAN}

Pada tahapan ini berisi hasil dari tahapan-tahapan penelitian berdasarkan metode penelitian ditunjukkan pada Gambar 2. Tahapan-tahapan penelitian tersebut terdiri dari pengumpulan Dataset Pima Indian Diabetes dari UCI Repository. Tahapan selanjutnya adalah data pre-processing, kemudian proses klasifikasi menggunakan metode Naive Bayes Classifier (NBC) dan Correlated Naive Bayes Classifier (C-NBC). Tahapan terakhir yaitu pengukuran kinerja berdasarkan akurasi dari metode yang digunakan.

Proses klasifikasi dilakukan setelah melalui tahapan data pre-processing. Klasifikasi merupakan salah satu tugas dari data mining. Klasifikasi adalah proses untuk menentukan suatu item dari dataset kedalam label kelas. Penelitian ini menggunakan metode klasiikasi Naive Bayes Classifier (NBC) dan Correlated Naive Bayes Classifier (C-NBC).

Proses klasifikasi dengan algoritme Nä̈ve Bayes Classifier (NBC) dan Correlated Nä̈ve Bayes Classifier (C-NBC) dilakukan dengan aplikasi Java. Proses klasifikasi dilakukan 
dengan teknik pengujian dengan algoritme Nä̈ve Bayes Classifier (NBC) dan Correlated Naive Bayes Classifier (CNBC) terhadap dataset dengan metode 10-Fold Cross Validation dari hasil pengacakan dataset sebanyak 30 kali secara random.

Dataset yang digunakan pada penelitian ini yaitu Dataset Pima Indian Diabetes. Setelah melakukan proses klasifikasi menggunakan algoritme Naive Bayes Classifier (NBC) dan Correlated Naive Bayes Classifier (C-NBC) dari hasil pengacakan dataset sebanyak 30 kali secara random dengan metode 10-Fold Cross Validation diperoleh rata-rata akurasi Dataset Pima Indian Diabetes yang ditunjukkan pada tabel 3 dan Tabel 4.

TABEL 3

RATA-RATA AKURASI DATASET PIMA INDIAN DIABETES

\begin{tabular}{|c|c|c|}
\hline No & C-NBC & NBC \\
\hline 1. & 67,89 & 63,95 \\
\hline 2. & 67,5 & 63,95 \\
\hline 3. & 67,37 & 64,34 \\
\hline 4. & 66,71 & 63,82 \\
\hline 5. & 67,37 & 65,53 \\
\hline 6. & 66,97 & 64,47 \\
\hline 7. & 67,37 & 64,87 \\
\hline 8. & 67,24 & 63,29 \\
\hline 9. & 67,37 & 63,68 \\
\hline 10. & 67,24 & 64,74 \\
\hline 11. & 67,11 & 65,53 \\
\hline 12. & 66,84 & 64,34 \\
\hline 13. & 66,18 & 61,97 \\
\hline
\end{tabular}

TABEL 4

RATA-RATA AKURASI DATASET PIMA INDIAN DIABETES (LANJUTAN)

\begin{tabular}{|c|c|c|}
\hline No & C-NBC & NBC \\
\hline 14. & 67,11 & 64,08 \\
\hline 15. & 67,5 & 64,74 \\
\hline 16. & 67,37 & 63,29 \\
\hline 17. & 66,97 & 63,29 \\
\hline 18. & 66,58 & 65 \\
\hline 19. & 67,63 & 64,47 \\
\hline 20. & 67,11 & 65,66 \\
\hline 21. & 67,5 & 64,61 \\
\hline 22. & 66,71 & 63,55 \\
\hline 23. & 67,24 & 63,68 \\
\hline 24. & 66,84 & 64,34 \\
\hline
\end{tabular}

\begin{tabular}{|l|l|l|}
25. & 67,11 & 66,97 \\
\hline 26. & 67,37 & 64,61 \\
\hline 27. & 66,97 & 63,68 \\
\hline 28. & 67,24 & 63,95 \\
\hline 29. & 67,24 & 65,13 \\
\hline 30. & 66,71 & 64,34 \\
\hline
\end{tabular}

Untuk mempermudah melihat perbandingan akurasi algoritme Correlated Naive Bayes Classifier dan Naive Bayes Classifier terhadap dataset Pima Indian Diabetes berdasarkan hasil pengujian yang dilakukan ditunjukkan pada Gambar 4.

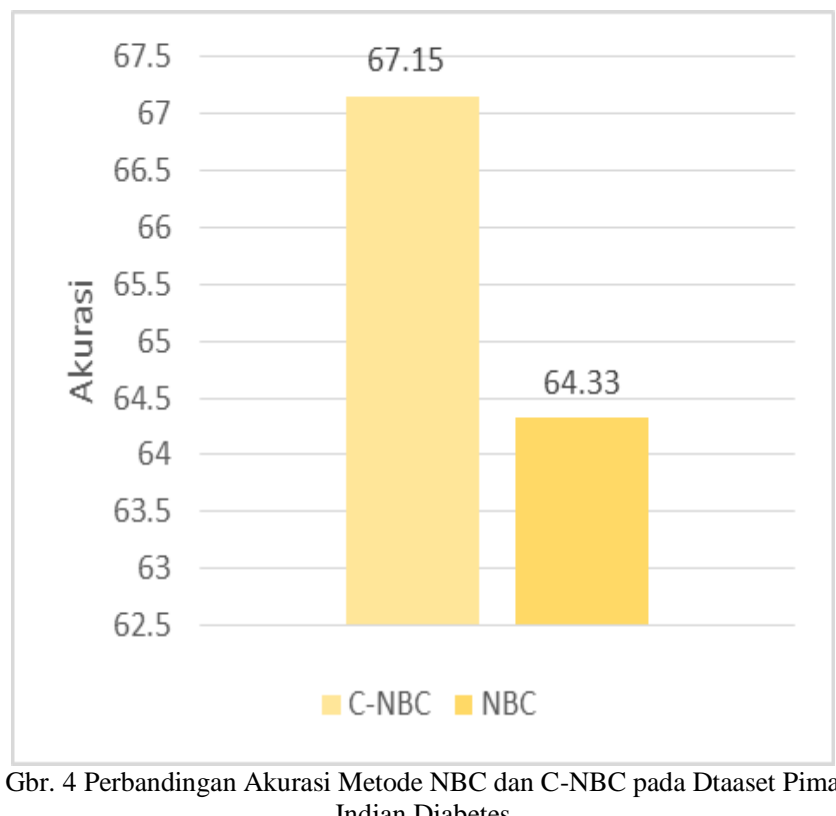

Berdasarkan Gambar 4 diatas, ditunjukkan bahwa nilai akurasi tertinggi pada Dataset Pima Indian Diabetes di peroleh dengan metode Correlated Naive Bayes Classifier (CNBC) yaitu sebesar $67,15 \%$ dibandingkan dengan metode Naive Bayes Classifier (NBC) sebesar 64,33\%. Hasil tertinggi untuk akurasi pada dataset tersebut diperoleh oleh metode $\mathrm{C}$ NBC dibandingkan metode NBC adalah karena pada metode Correlated Naive Bayes Classifier (C-NBC) memperhitungkan nilai korelasi (R-Square) dari masingmasing atribut dataset terhadap kelasnya. Hal ini selaras dengan pendapat dar referensi [9] mengatakan bahwa penambahan parameter perhitungan korelasi pada metode Naive Bayes Classifier dapat meningkatkan akurasi secara significant.

\section{KESIMPULAN}

Berdasarkan pengujian yang telah dilakukan menunjukkan bahwa metode Correlated Naive Bayes Classifier (CNBC) memperoleh akurasi terbaik dibandingkan dengan metode 
Naive Bayes Classifier (NBC) untuk Dataset Pima indian Diabetes. Tingkat akurasi metode Correlated Naive Bayes Classifier (CNBC) sebesar $67,15 \%$, sedangkan metode Naive Bayes Classifier (NBC) sebesar 64,33\%. Metode Correlated Naive Bayes Classifier (C-NBC) memiliki akurasi lebih tinggi dibandingkan metode Nä̈ve Bayes Classifier (NBC) karena pada metode Correlated Nä̈ve Bayes Classifier memperhitungkan nilai korelasi (R-Square) dari masingmasing atribut dataset terhadap kelasnya. Dengan demikian penggunaan metode Correlated Nä̈ve Bayes Classifier (CNBC) dapat digunakan untuk melakukan diagnosis penyakit diabetes karena memiliki tingkat akurasi yang bagus.

\section{UCAPAN TERIMA KASIH}

Terima kasih saya ucapkan kepada LPPM STMIK Bumigora Mataram atas dukungannya dalam terlaksananya penelitian ini.

\section{DAFTAR PUSTAKA}

[1] WHO, "World Diabetes Day 2015," 2005. [Online]. Available: http://www.who.int/diabetes/wdd_2015/en/. [Accessed: 24-Apr-2018].

[2] Who, "10 Facts on Diabetes," 2016. [Online]. Available:

http://www.who.int/features/factfiles/diabetes/en/. [Accessed: 24-Apr-2018].

[3] Who, "Diabetes," 2015. [Online]. Available: http://www.who.int/diabetes/en/. [Accessed: 24-Apr2018].

[4] B. A. Muktamar, N. A. Setiawan, and T. B. Adji, "Pembobotan Korelasi pada Naive Bayes Classifier," Semin. Nas. Teknol. Inf. dan Multimed. 2015 STMIK AMIKOM Yogyakarta, 6-8 Februari 2015, no. 1, pp.
43-47, 2015

[5] S. N. N. Alfisahrin and T. Mantoro, "Data Mining Techniques for Optimization of Liver Disease Classification," 2013 Int. Conf. Adv. Comput. Sci. Appl. Technol., pp. 379-384, 2013.

[6] C. Shah and A. G. Jivani, "Comparison of Data Mining Classification Algorithms for Breast Cancer Prediction," Comput. Commun. Netw. Technol. (ICCCNT), 2013 Fourth Int. Conf., vol. 4, pp. 4-7, 2013.

[7] J. Han and M. Kamber, Data Mining Concepts and Techniques, Second. Francisco: Morgan Kaufmann, 2006.

[8] B. A. Muktamar, N. A. Setiawan, and T. B. Adji, "Correlated Naive Bayes Classifier," Universitas Gadjah Mada, 2015.

[9] B. A. Muktamar, N. A. Setiawan, and T. B. Adji, "Analisis Perbandingan Tingkat AKurasi Algoritma Naive Bayes Classifier dengan Correlated-Naive Bayes Classifier," Semin. Nas. Teknol. Inf. dan Multimed. 2015 STMIK AMIKOM Yogyakarta, 6-8 Februari 2015, pp. 49-54, 2015. 